\title{
Modifying Effects of Lemongrass Essential Oil on Specific Tissue Response to the Carcinogen $N$-Methyl- $N$-Nitrosurea in Female BALB/c Mice
}

\author{
Lucas T. Bidinotto, ${ }^{1,2}$ Celso A.R.A. Costa, ${ }^{3}$ Mirtes Costa, ${ }^{3}$ Maria A.M. Rodrigues, ${ }^{2}$ \\ and Luís F. Barbisan ${ }^{1,2}$ \\ Departments of ${ }^{1}$ Morphology and ${ }^{3}$ Pharmacology, Institute of Biosciences; and ${ }^{2}$ Department of Pathology, \\ Faculty of Medicine, São Paulo State University, Botucatu, São Paulo, Brazil.
}

\begin{abstract}
Lemongrass (Cymbopogon citratus Stapf) essential oil has been used worldwide because of its ethnobotanical and medicinal usefulness. Regarding its medicinal usefulness, the present study evaluated the beneficial effects of lemongrass essential oil (LGEO) oral treatment on cell proliferation and apoptosis events and on early development of hyperplastic lesions in the mammary gland, colon, and urinary bladder induced by $N$-methyl- $N$-nitrosourea (MNU) in female BALB/c mice. The animals were allocated into three groups: G1, treated with LGEO vehicle for 5 weeks (five times per week); G2, treated with LGEO vehicle as for G1 and MNU (two injections each of $30 \mathrm{mg} / \mathrm{kg}$ of body weight at weeks 3 and 5); and G3, treated with LGEO (five times each with $500 \mathrm{mg} / \mathrm{kg}$ of body weight per week) and MNU as for G2. Twenty-four hours after the last MNU application, all animals were euthanized, and mammary glands, colon, and urinary bladder were collected for histological and immunohistochemical analysis. LGEO oral treatment significantly changed the indexes of apoptosis and/or cellular proliferation for the tissues analyzed. In particular, the treatment reduced the incidence of hyperplastic lesions and increased apoptosis in mammary epithelial cells. This increment in the apoptosis response may be related to a favorable balance in Bcl2/Bax immunoreactivity in mammary epithelial cells. These findings indicate that LGEO presented a protective role against early MNU-induced mammary gland alterations in BALB/c mice.
\end{abstract}

KEY WORDS: • apoptosis $\bullet$ cell proliferation $\bullet$ female BALB/c mice $\bullet$ lemongrass essential oil $\bullet \mathrm{N}-$ methyl-N-nitrosourea

\section{INTRODUCTION}

$\mathbf{E}$ SSENTIAL OIL OF AROMATIC PLANTS has been used by industries in the production of soaps, perfumes, and toiletries. In addition, many such oils have been used in traditional medicine for various purposes because some of them exhibit antibacterial, antifungal, and insecticidal properties. ${ }^{1,2}$

Lemongrass (Cymbopogon citratus Stapf) leaves have been widely consumed as infusions or decoctions in Brazilian folk medicine to treat ailments because of their antispasmodic, analgesic, anti-inflammatory, antipyretic, diuretic, and sedative properties. ${ }^{3,4}$ In addition, lemongrass essential oil (LGEO) has an immense commercial value as a food preservative, flavoring agent, and ingredient in fragrances and cosmetics. $^{2}$ Also, various in vitro and in vivo pharmacological activities of LGEO have been described, including anxiolytic and anticonvulsant activities, ${ }^{4,5}$ antibacterial, antifungal, and antiprotozoal properties, ${ }^{6-10}$ potential immunostimulating action, and antiviral activity against herpes simplex virus type $1 .^{11,12}$

Manuscript received 7 October 2010. Revision accepted 14 July 2011.

Address correspondence to: Luís F. Barbisan, Department of Morphology, Institute of Biosciences, São Paulo State University, 18618-900, Botucatu, SP, Brazil, E-mail: barbisan@ibb.unesp.br
Previous in vitro and in vivo studies have shown antimutagenic and antioxidant activities of lemongrass extracts or their main compounds (i.e., citral, $\beta$-myrcene, and geraniol). ${ }^{13-19}$ Moreover, geraniol has been found to reduce the proliferative activity of Caco-2 human colon and MCF-7 human cancer cell lines. ${ }^{20,21}$ In addition, lemongrass ethanolic extract, orally given to male Fischer 344 rats, inhibited colonic aberrant crypt foci (ACF) and glutathione $S$-transferase placental form-positive foci development induced by azoxymethane and diethylnitrosamine, respectively. ${ }^{22,23}$

Despite of these data, there is no information about the beneficial action of LGEO oral treatment on carcinogeninduced target organ toxicity and early development of preneoplastic lesions in mice. Thus, the present study aimed to determine whether LGEO could influence the acute proliferative and apoptotic responses induced by the carcinogen $N$-methyl- $N$-nitrosourea $(\mathrm{MNU})$ in the mammary gland, colon, and urinary bladder of female BALB/c mice.

\section{MATERIALS AND METHODS}

\section{LGEO extraction}

Plant seedlings of specimens from the garden of medicinal plants at Lageado Farm, São Paulo State University, 
were cultivated at the Institute of Biosciences campus, Botucatu, SP, Brazil. The plant was identified in the BOTU Herbarium, Department of Botany, São Paulo State University, where a voucher specimen (number 23031) was deposited. The LGEO was extracted from fresh lemongrass leaves through 3 hours of boiling hydrodistillation using a Clevenger apparatus. The extracted LGEO was stored at $4^{\circ} \mathrm{C}$ in a dark vessel up to the moment of use.

The chromatographic oil profile of each extraction was acquired in silica plates (Sigma-Aldrich, St. Louis, MO, USA), using hexane plus ethyl acetate or toluene plus ethyl acetate as mobile phases. LGEO samples or its main compounds (citral, geraniol and $\beta$-myrcene) were diluted in dichloromethane and applied to the plate through capillary tubes. Then, the plates were put into saturated cubes with eluent, after which the compounds were separated through affinity chromatography; plates were revealed by sulfuric anisaldehyde. In addition, the plates were heated to a temperature of $100^{\circ} \mathrm{C}$ for 5 minutes and immediately photographed. To avoid differences in LGEO constitution among the extractions, the essential oils acquired on each extraction were mixed and then used for the purposes of this study. Finally, the essential oil mixture was analyzed by gas chromatography coupled with mass spectrometry according to the following conditions: injection of $1 \mu \mathrm{L}$ of the solution ( $1 \mu \mathrm{L}$ of LGEO and $1 \mathrm{~mL}$ of ethyl acetate); silica capillary column of DB-5 $(30 \mathrm{~m} \times 0.25 \mathrm{~mm}$; particle size, $0.25 \mu \mathrm{m})$; electron impact, $70 \mathrm{eV}$; utilizing helium at $1.0 \mathrm{~mL} /$ minute as the carrier gas; injector temperature, $240^{\circ} \mathrm{C}$; detector temperature, $230^{\circ} \mathrm{C}$; and temperature program, from $60^{\circ} \mathrm{C}$ to $240^{\circ} \mathrm{C}, 3^{\circ} \mathrm{C} /$ minute. The compounds were identified through substance mass spectrum comparison with the gas chromatography/mass spectrometry database (NIST 62 library), literature values, and retention indexes. ${ }^{24,25}$

\section{Experimental design}

The animals were handled in accordance with the Ethical Principles for Animal Research adopted by the Brazilian College of Animal Experimentation and approved by the Committee for Ethics in Animal Experimentation at Botucatu Medical School, São Paulo State University. Female BALB/c mice were obtained from the Multidisciplinary Center for Biological Investigation (Campinas, SP, Brazil) and housed in polypropylene cages covered with metallic grids in a room maintained at $22 \pm 2^{\circ} \mathrm{C}$ and $55 \pm 10 \%$ humidity and with a 12-hour lightdark cycle. The animals were fed with commercial Purina chow (LABINA, Paulínia, SP, Brazil) and water ad libitum for a 2 -week acclimation period. Then, the mice were allocated into three groups (10 mice per group): G1, negative control, received by gavage the LGEO vehicle ( $2 \%$ Tween 20, five times a week for 5 weeks); G2, positive group, received by gavage the LGEO vehicle ( $2 \%$ Tween 20 , five times a week for 5 weeks) and two intraperitoneal injections of MNU (Sigma-Aldrich) (each at $30 \mathrm{mg} / \mathrm{kg}$ at the end of weeks 3 and 5); ${ }^{26}$ and G3, test group, received by gavage LGEO $(500 \mathrm{mg} / \mathrm{kg}$ of body weight, five times a week for 5 weeks) and the two MNU intraperitoneal injections. All animals were euthanized at 24 hours after the last MNU application. The LGEO dosage adopted here was based on our previously published work. ${ }^{4}$

Clinical examinations were performed daily, and detailed physical evaluations were done weekly. Food and water consumption were recorded twice a week. The animals were fasted overnight and euthanized by exsanguination under sodium pentobarbital anesthesia ( $45 \mathrm{mg} / \mathrm{kg}$ of body weight).

\section{Processing and analysis of tissues}

At necropsy, the inguinal mammary glands, colon, and urinary bladder were removed and fixed in $10 \%$ buffered formalin for 24 hours for posterior histological analysis. The mammary gland fat pads were processed for paraffin embedding. The urinary bladder was inflated with $10 \%$ phosphate-buffered formalin, cut in four to six strips, and processed for paraffin embedding. The entire colon was longitudinally opened, rinsed in saline, and flat-mounted in fixative solution. Colons were stained with $2 \%$ methylene blue in phosphate-buffered saline for 10 minutes for ACF counting. ${ }^{27,28}$ After ACF analysis, proximal, middle, and distal colon samples were cut into serial strips and processed for paraffin embedding.

Paraffin blocks with the target organs were cut in 5- $\mu \mathrm{m}$ thick sections and stained with hematoxylin and eosin for histological or immunohistochemical analysis. In hematoxylin and eosin-stained slides, preneoplastic lesions were analyzed in order to evaluate the protective effects of LGEO in early initiation phase of carcinogenesis. Mammary lesions were classified as alveolar/ductal hyperplasia, colon lesions as ACF, and urothelial lesions as simple or nodular hyperplasia, according to previously published criteria. ${ }^{26,28-30}$ Under hematoxylin and eosin staining, apoptotic cells were identified by typical morphological criteria as previously described. ${ }^{26,30,31}$

Immunohistochemical staining for proliferation cellular nuclear antigen (PCNA) was performed using the streptavidin-biotin peroxidase method, according to previously established procedures. ${ }^{32}$ In brief, deparaffinized 5 - $\mu \mathrm{m}$ thick sections were subjected to antigenic detection by $0.1 \mathrm{M}$ citric acid (two cycles of 5 minutes each in a microwave oven) and were treated with 3\% hydrogen peroxide for 10 minutes, nonfat milk for 60 minutes, anti-PCNA antibody (1:100 dilution, Dako, Glostrup, Denmark) conjugated with anti-mouse antibody (1:200 dilution, Dako) overnight, and streptavidin-biotin peroxidase solution (1:50 dilution, Vector Laboratories, Burlingame, CA, USA) for 45 minutes. Chromogen color development was accomplished with 3,3diaminobenzidine tetrahydrochroride (Sigma-Aldrich), and counterstaining was performed with Harris's hematoxylin.

Cell proliferation and apoptotic indexes were expressed as the percentage of PCNA S phase-positive cells or apoptotic cells/apoptotic bodies among the total number of cells counted, respectively. ${ }^{26,30}$ Cell proliferation and apoptosis indexes were analyzed in order to evaluate the LGEO protective effects on acute proliferative and apoptotic responses 
induced by the carcinogen MNU in the mammary gland, colon, and urinary bladder.

\section{Apoptosis biomarker analysis}

As apoptosis is an important event in the eradication of cells that are suffering DNA insult due to genotoxic chemicals or radiation exposures, ${ }^{31,32}$ apoptotic biomarkers were investigated by in situ protein expression, including $\mathrm{Bcl}-2$ protein (anti-polyclonal rabbit anti-Bcl-2 [N-19] at 1:200 dilution, Santa Cruz Biotechnology Inc., Santa Cruz, CA, USA) and Bax protein (anti-polyclonal rabbit anti-bax [G-23] at 1:200 dilution, Santa Cruz Biotechnology Inc.) by immunohistochemical reaction as described above. Mammary gland was chosen for this analysis because of the lower incidence of proliferative/preneoplastic lesions and increased apoptosis indexes found in the LGEO+MNU-treated group compared with the MNU alone-treated group (see Results). The expression level of the regulatory apoptotic proteins Bcl-2 and Bax was evaluated by using a semiquantitative score $(0$, lack of expression; +1 , weak expression; $2+$, medium expression; $3+$, strong expression) and counting 10 random microscopic fields consecutively for each mouse ( $\times 40$ objective).

\section{Statistical analysis}

Body weight and food consumption and cell proliferation and apoptosis indexes were compared among the experimental groups using analysis of variance or Kruskal-Wallis tests with a posteriori contrast tests, when necessary. Bcl-2 and Bax scores were analyzed using Kruskal-Wallis tests. The incidence of preneoplastic lesions was compared by $\chi^{2}$ or by the Fisher test. The significance level adopted was $P<.05$. The statistical analyses were performed using Sigma Stat software (Jandel Corp., San Rafael, CA, USA).

\section{RESULTS}

The compounds of the essential oil used in this study and their relative percentages are shown in the gas chromatography/mass spectrometry chromatogram of Figure 1. The major compounds found in lemongrass were citral (neral and geranial), geraniol, and $\beta$-myrcene, representing $89.07 \%$ of the total oil; the remaining percentage was the compounds 6-methyl-5-hepten-2-one and undeca-2-one as previously described by other investigators. ${ }^{33,34}$

No significant variation in food or water consumption was observed during the 5-week experimental period, and final body weights were similar among the groups (data not shown). At the end of week 5, proliferative and/or preneoplastic lesions induced by the MNU applications were detected in the mammary glands (e.g., alveolar/ductal hyperplasia), colon (e.g., ACF), and urinary bladder (e.g., simple or nodular hyperplasia) of the female $\mathrm{BALB} / \mathrm{c}$ mice. A significant reduction $(40 \%$ vs. $100 \%, P<.05)$ of alveolar/ ductal hyperplasia incidence was observed in the LGEO+ MNU-treated group (G3) compared with the MNU-treated group (G2) (Table 1). Nevertheless, there were no clear differences in colonic ACF incidence $(100 \%$ vs. $100 \%)$ and multiplicity (i.e., aberrant crypts per ACF, $2.12 \pm 0.32$ vs. $2.21 \pm 0.31$ ) or urothelial simple or nodular hyperplasia incidence (40\% vs. 50\%) between the MNU-treated groups (G2 and G3) (Table 1). No proliferative and/or preneoplastic lesions were detected in vehicle-treated mice (group G1) (Table 1).

Percentage PCNA S phase-labeling and apoptosis indexes in the mammary gland, colon, and urinary bladder 24 hours after MNU treatment are presented in Figure 2. MNU administration induced an increase in the cell proliferation index in the colon (i.e., non-altered crypt epithelial cells) and in the urinary bladder (i.e., non-altered urothelial epithelial cells) compared with the vehicle-treated group (G2 vs. G1, $.05<P<.001$ ), but not in the mammary gland (i.e., nonaltered alveolar/ductal epithelial cells). Moreover, apoptotic indexes were higher in the colon and urinary bladder of MNU-treated mice but lower in the mammary gland, compared with the vehicle-treated group (G2 vs. G1, $.05<P<.001)$. On the other hand, LGEO $(500 \mathrm{mg} / \mathrm{kg})$ treatment for 5 weeks significantly reduced both cell proliferation and apoptotic indexes in urothelial epithelial cells compared with the MNU-treated group (G3 vs. G2, $.05<P<.01)$ and the apoptotic index in colonic epithelial cells. In contrast, LGEO treatment significantly reduced cell proliferation but increased the apoptosis index in the mammary gland compared with the MNU-treated group (G3 vs. G2, $P<.05$ ).

Bcl-2 and Bax proteins were immunohistochemically localized in the cytoplasm of mammary epithelial cells of

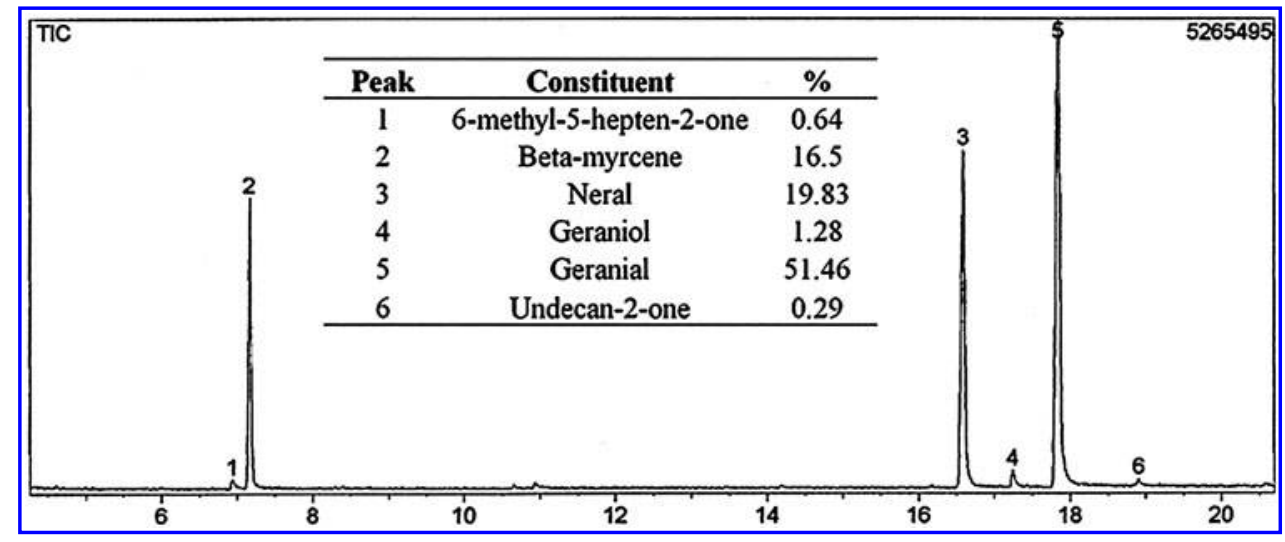

FIG. 1. Chromatogram and chemical composition obtained by gas chromatography coupled with mass spectrometry from C. citratus essential oil. 
Table 1. Incidence and Multiplicity

of Preneoplastic/Proliferative Lesions

in Mammary Gland, Colon, and Urinary Bladder of Female BALB/C Mice

\begin{tabular}{lccc}
\hline & \multicolumn{3}{c}{ Treatment group } \\
\cline { 2 - 4 } & $\begin{array}{c}\text { Vehicle } \\
(G 1)\end{array}$ & MNU & LGEO+MNU \\
Organ, lesion & & & $(G 3)$ \\
\hline Mammary gland & & & \\
$\quad$ Alveolar/ductal & & \\
$\quad$ hyperplasia & & & \\
$\quad$ Incidence & 0 & $100 \%$ & $40 \% *$ \\
$\quad$ Multiplicity & 0 & $1.20 \pm 0.13$ & $0.43 \pm 0.20^{* *}$ \\
Colon & & & \\
ACF & & & $100 \%$ \\
$\quad$ Incidence & 0 & $100 \%$ & $9.30 \pm 2.37$ \\
$\quad$ Total AC & 0 & $8.86 \pm 2.26$ & $4.00 \pm 2.37$ \\
$\quad$ Total ACF & 0 & $4.30 \pm 1.08$ & \\
$\quad$ Multiplicity (AC/ACF) & 0 & $2.21 \pm 0.31$ & $2.12 \pm 0.32$ \\
Urinary bladder & & & \\
Simple/nodular & & & \\
$\quad$ hyperplasia & & & \\
$\quad$ Incidence & & & \\
$\quad$ Multiplicity & 0 & $1.50 \pm 1.23$ & $1.60 \pm 1.36$ \\
\hline
\end{tabular}

Data are percentage incidence (percentage of mice bearing lesion) or mean \pm SEM multiplicity (mean number of lesions per mouse per group).

Statistically different from group G2: $* P<.05, * * P=.027$. Group G3 was compared only with group G2.

AC, aberrant crypt; ACF, aberrant crypt foci; LGEO, lemongrass essential oil $(500 \mathrm{mg} / \mathrm{kg}$, five times per week for 5 weeks); MNU, $N$-methyl- $N$ nitrosourea (two injections each of $30 \mathrm{mg} / \mathrm{kg}$ of body weight, at the end of weeks 3 and 5).

terminal buds, ducts, and alveoli (Fig. 3A and B). The average score levels of Bcl-2 expression were significantly lower $(P=.027)$ in mammary epithelial cells of the LGEO+MNUtreated group (G3) than in the vehicle-treated and MNU alone-treated groups (G1 and G2, respectively) (Fig. 3C). In contrast, Bax expression was significantly higher $(P=.014)$ in the LGEO+MNU-treated group (G3) compared with the other groups (G1 and G2) (Fig. 3D). The average score levels of Bcl-2/Bax ratio was also significantly lower $(P=.002)$ in MNU-treated groups (G2 and G3) than in the vehicle-treated group (G1) (Fig. 3E).

\section{DISCUSSION}

The present study was designed to investigate the possible modifying effects of LGEO on chemically induced target organ toxicity and surrogate proliferative/preneoplastic lesion development in female BALB/c mice. The findings of this study indicated that LGEO oral administration, before and during MNU exposure, reduced target organ cytotoxicity (i.e., cell proliferation and/or apoptosis responses) in colonic crypt and bladder urothelial epithelial cells. LGEO treatment also increased apoptosis in mammary epithelial cells (i.e., terminal buds, alveolus, and ducts) compared with the MNUtreated group and significantly reduced the early development of proliferative/preneoplastic lesions in this organ.
MNU is a direct methylating agent that reacts with cellular macromolecules, including DNA, causing relatively high levels of $O^{6}$-methylguanine, which results in a predominant DNA lesion. ${ }^{35}$ Epidemiological and experimental studies have shown a strong correlation between the occurrence of $O^{6}$-methylguanine and cancer development. ${ }^{36,37}$ Therefore, MNU has been used as a potent carcinogen in chemically induced rodent mammary gland, colon, and urinary bladder carcinogenesis models, ${ }^{26,38-40}$ and it has been demonstrated to exert acute cytotoxicity on mammary, colonic, and urothelial epithelial cells by inducing cell death. ${ }^{41-43}$

The acute treatment with MNU increased the apoptotic levels in the colon and urinary bladder probably because of DNA damage in the epithelial cells. Moreover, LGEO oral treatment reduced the deleterious effects of MNU exposure detected by the lower cell proliferation index in the urinary bladder and the lower apoptotic index in both the colon and urinary bladder, without an effective action against early preneoplasia development. Thus, LGEO oral treatment only attenuated the cytotoxic effects of the carcinogen in these target organs. It is interesting that LGEO oral treatment not only increased apoptosis, but also reduced cell proliferation in the mammary gland, resulting in a protective action against mammary hyperplasia development. In fact, there are hallmarks of the range of complex steps that occur during tumor development. Sustained proliferative signaling, resistance to cell death, and replicative immortality are included among them. ${ }^{44}$ The disruption of the proliferation/ apoptosis normal balance toward proliferative activity may lead to hyperplasia of the cells, which may result in tumor growth. ${ }^{45,46}$ Shilkaitis et al. ${ }^{45}$ demonstrated, like our findings, that cell proliferation is similar in both normal mammary tissue and hyperplastic terminal end buds. However, apoptosis is relatively high in normal terminal end buds and decreases in the hyperplastic terminal end buds of MNUtreated female Sprague-Dawley rats. The differential responses of mouse mammary gland, colon, and urinary bladder to MNU exposure could be due to differences in organ microenvironments and/or because of the metabolic and DNA repair machinery. ${ }^{47}$

Apoptosis is an important regulatory process in the protection against the development of cancer. It provides an innate cellular defense against tumorigenesis by removing cells with genomic instability and by deleting cells with DNA damage induced by genotoxic agents such as carcinogens. ${ }^{31,32}$ Moreover, the increase or facilitation of apoptosis during initiation events of chemical carcinogenesis increases the elimination of mutated cells that may otherwise progress to malignancy after a long period of latency. ${ }^{31,32}$ The regulators of apoptosis are divided into two major programs: the extrinsic program involves extracellular death signals, and the intrinsic program involves signals of intracellular origin. ${ }^{44}$ DNA damage is one of the events able to trigger the intracellular death signals. ${ }^{48}$ Both intrinsic and extrinsic apoptotic programs involve the activation and/or suppression of various gene families. Among these families, $\mathrm{Bcl}-2$ protein and other members of its family protect the cells from apoptosis, whereas $\mathrm{Bax}$ and related proteins potentiate the 

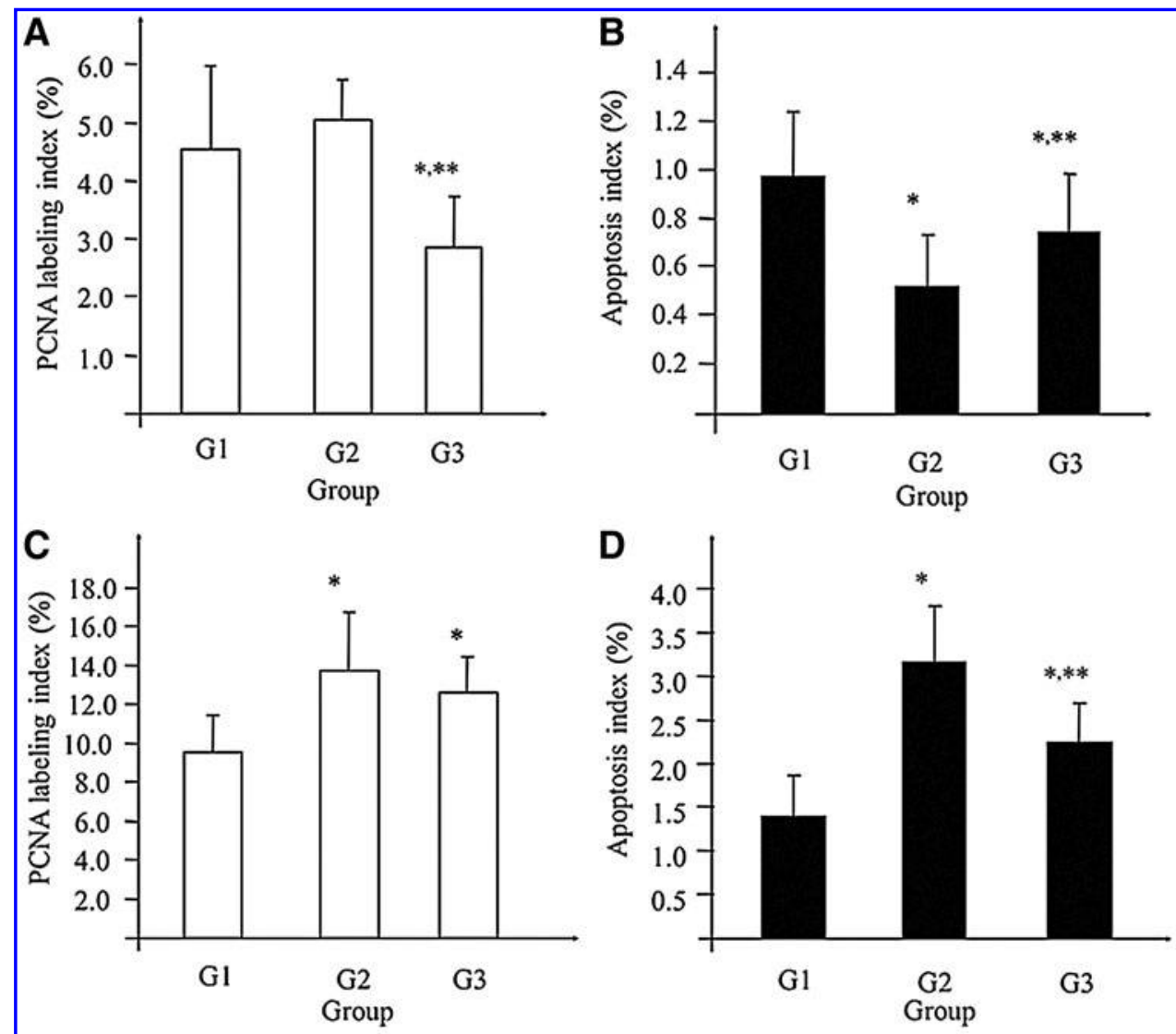

FIG. 2. Proliferation cellular nuclear antigen (PCNA) labeling index (\%) and apoptosis index (\%) for (A and $\mathbf{B}$, respectively) alveolar/ductal mammary epithelial cells, ( $\mathbf{C}$ and $\mathbf{D}$, respectively) colonic crypt epithelial cells, and $(\mathbf{E}$ and $\mathbf{F}$, respectively) urothelial cells. Statistically different from groups G1 $(*)$ and $\mathrm{G} 2(* *)(.05<P<.01)$.
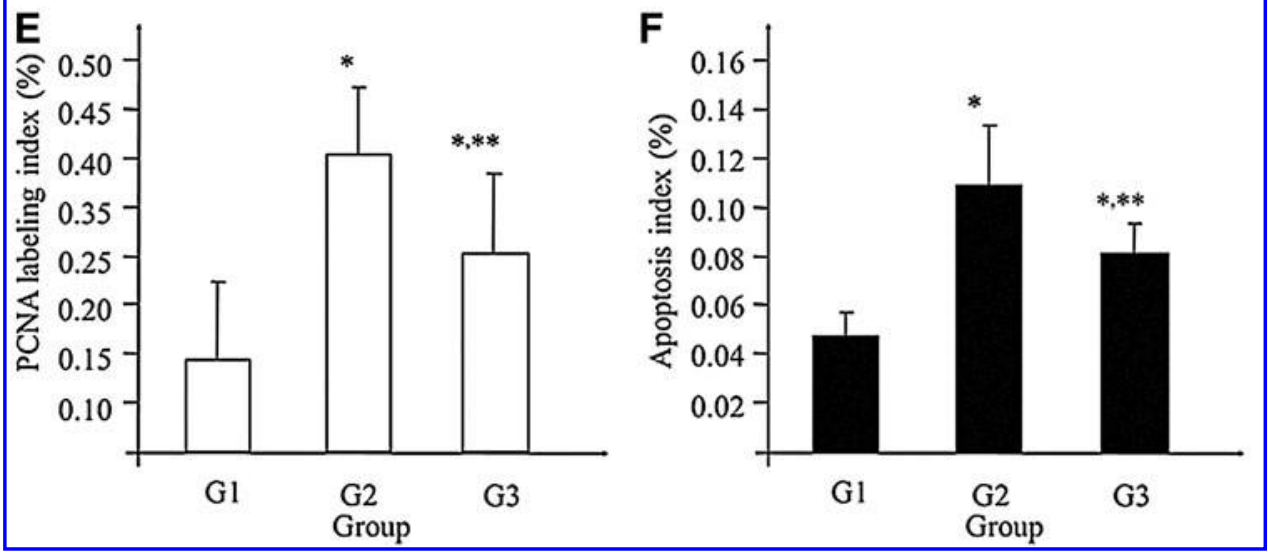

cell death. ${ }^{49,50}$ The Bcl-2/Bax ratio intrinsically controls the relative susceptibility of cells to induction of apoptosis. ${ }^{49,50}$ Bcl-2 and Bax are differentially expressed in various tissues and cell populations, including mammary gland. ${ }^{51,52}$ In human and rodent mammary gland, Bcl-2 and Bax proteins are constitutively expressed in normal epithelial cells but variably expressed in preneoplastic and neoplastic lesions. ${ }^{51,52}$ Although MNU administration in itself slightly decreased the $\mathrm{Bcl}-2 / \mathrm{Bax}$ ratio in our study (maybe because of the activation of the DNA repair machinery, which is able to trigger apoptotic signals, for example, through p53 activity), ${ }^{4,48}$ LGEO oral treatment effectively increased apoptosis after treatment with MNU, suggesting that it may be protective in the early stages of mammary carcinogenesis. Therefore, the mechanism by which LGEO protected the mammary gland from the cancer initiation may be by changing the balance of Bcl-2/Bax in situ expression toward apoptosis increase. Thus, we assumed that the slight decrease of Bcl-2/Bax ratio in the MNU-treated group was a consequence of the DNA repair machinery activation, but other signals (i.e., the inactivation of the extrinsic apoptotic program) could be responsible for the decrease in the apoptotic levels. The lower Bcl-2/Bax ratio caused by LGEO treatment was responsible for the higher apoptotic index than in the MNUtreated group.

Putative preneoplastic lesions have been well characterized in mice as alveolar/ductal hyperplasia in the mammary glands, $\mathrm{ACF}$ in the colon, and simple and nodular 


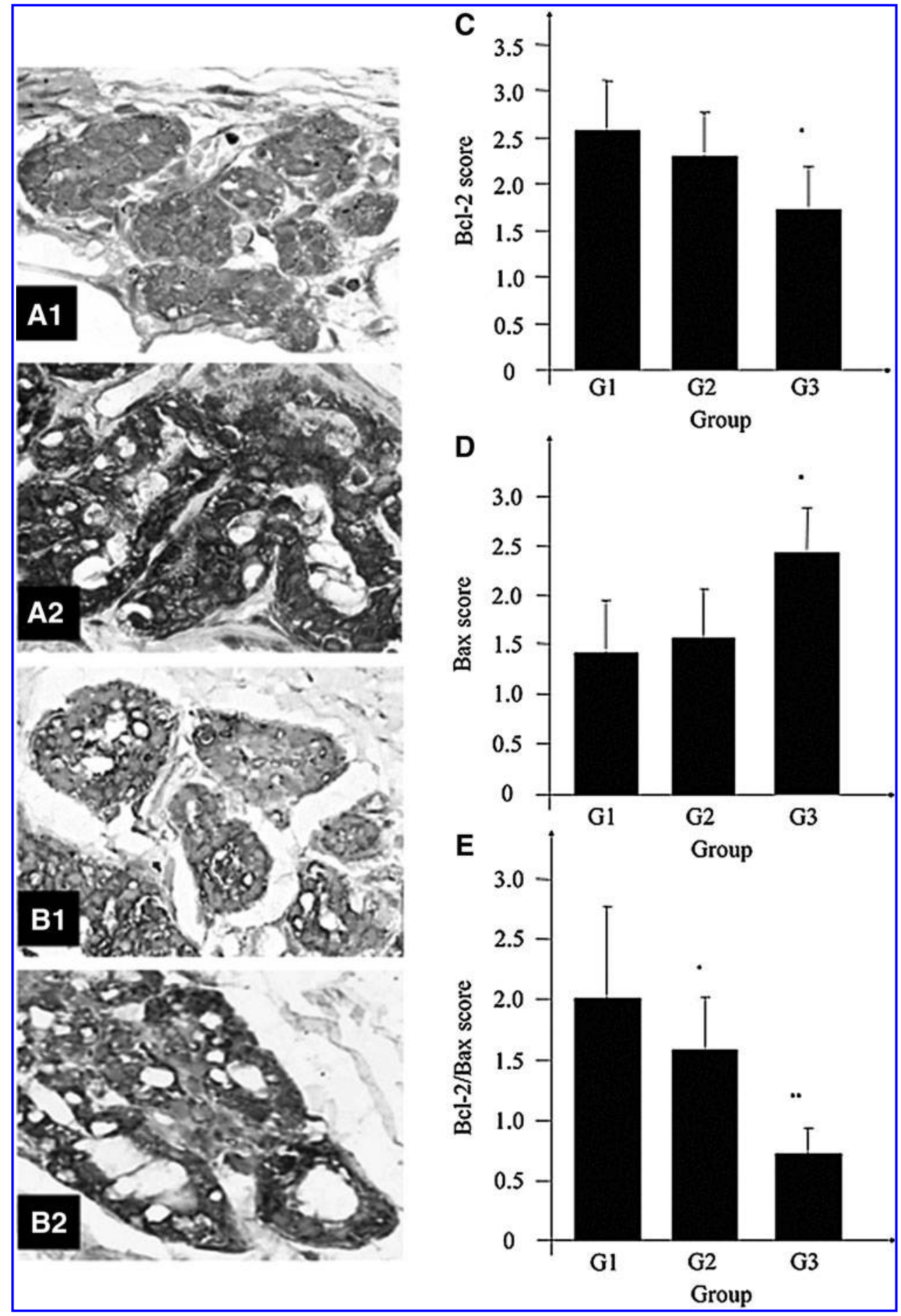

FIG. 3. Mammary gland images labeled immunohistochemically for (A) Bcl-2 and (B) Bax proteins: weak cytoplasmic immunoreactivity for (A1) Bcl-2 and (B1) Bax and strong cytoplasmic immunoreactivity for (A2) Bcl-2 and (B2) Bax. (C-E) Graphic representation of analysis of $\mathrm{Bcl}-2$, Bax, and $\mathrm{Bcl}-2 / \mathrm{Bax}$, respectively, scores. Statistically different from groups G1 $(*)$ and $\mathrm{G} 2 \quad(* *)$ $(P<.02)$.

hyperplasia in the urinary bladder ${ }^{53}$ Putative preneoplastic lesions have been considered potential surrogate end point biomarkers for the potential chemopreventive identification of agents capable of inhibiting or suppressing rodent chemical carcinogenesis at different stages. ${ }^{54} \mathrm{~A}$ few studies have been done on anticarcinogenic effects of lemongrass in chemically induced models in rodents based on surrogate preneoplastic lesions as end points. Dietary lemongrass extract given for a 6-week treatment reduced the number of glutathione $S$-transferase placental form-positive lesions per liver area and decreased the oxidative damage in the liver, assessed by 8-hydroxydeoxyguanosine in male F344 rats initiated by diethylnitrosamine $;^{23}$ in addition, dietary lemongrass ethanolic extract given for 5 weeks-before and during azoxymethane-initiation phase-or given during the post-initiation phase for 12 weeks reduced the ACF incidence. Similarly, in initiation protocols, lemongrass reduced levels of colonic $N^{7}$-methylguanine and $O^{6}$-methylguanine 
DNA adducts as well as fecal $\beta$-glucuronidase activity in male F344 rats and oxidative damage induced by tert-butyl hydroperoxide in an in vitro system. ${ }^{22}$ Using a multi-organ carcinogenesis bioassay, we recently demonstrated that the post-initiation treatment with LGEO presented a potential chemopreventive action against mammary carcinogenesis, but not against colon and urothelial carcinogenesis, in female $\mathrm{BALB} / \mathrm{c}$ mice. ${ }^{55}$ Thus, an effective influence of LGEO on the initiation stage of the mammary carcinogenesis, as demonstrated herein by reduction of hyperplastic lesions, should continue to be investigated, mainly in long-term bioassays.

In conclusion, our results indicated that LGEO modulated the colonic and urothelial cytotoxicity induced by the directacting carcinogen MNU, but with no reduction in development of preneoplastic/neoplastic lesions. However, LGEO oral treatment acted as a potential blocking agent against MNU-induced mammary damage by activating apoptosis of the potentially initiated cells. Further studies are warranted to better evaluate the mechanisms involved in the protective action of LGEO on the cytoxicity and carcinogenicity induced by MNU in female BALB/c mice as well as the safety of the administration of this essential oil to animals.

\section{ACKNOWLEDGMENTS}

The authors acknowledge the technical support provided by Paulo Roberto Cardoso and Paulo Cesar Georgete and thank Dr. Márcia Ortiz M. Marques and Dr. Roselaine Facanali (Laboratory of Natural Products, Institute of Agronomy, Campinas, SP, Brazil) for the gas chromatography/ mass spectrometry analysis of essential oil. L.T.B. and C.A.R.A.C. were recipients of fellowships from FAPESP (06/58174-0 and 06/07195-8, respectively).

\section{AUTHOR DISCLOSURE STATEMENT}

No competing financial interests exist.

\section{REFERENCES}

1. Bakkali F, Averbeck S, Averbeck D, Idaomar M: Biological effects of essential oils-a review. Food Chem Toxicol 2008;46:446-475.

2. Ganjewala D, Luthra R: Essential oil biosynthesis and regulation in the genus Cymbopogon. Nat Prod Commun 2010;5:163-172.

3. Negrelle RRB, Gomes EC: Cymbopogon citratus (DC.) Stapf: chemical composition and biological activities. Rev Bras Pl Med 2007;9:80-92.

4. Blanco MM, Costa CARA, Freire AO, Santos JG Jr, Costa M: Neurobehavioral effect of essential oil of Cymbopogon citratus in mice. Phytomedicine 2009;16:265-270.

5. Silva MR, Ximenes RM, da Costa JG, Leal LK, de Lopes AA, de Barros Viana GS: Comparative anticonvulsant activities of the essential oils (EOs) from Cymbopogon winterianus Jowitt and Cymbopogon citratus (DC) Stapf. in mice. Naunyn Schmiedebergs Arch Pharmacol 2010;381:415-426.

6. Duarte MC, Leme EE, Delarmelina C, Soares AA, Figueira GM, Sartoratto A: Activity of essential oils from Brazilian medicinal plants on Escherichia coli. J Ethnopharmacol 2007;111:197-201.
7. Santoro GF, Cardoso MG, Guimarães LG, Freire JM, Soares MJ: Anti-proliferative effect of the essential oil of Cymbopogon citratus (DC) Stapf (lemongrass) on intracellular amastigotes, bloodstream trypomastigotes and culture epimastigotes of Trypanosoma cruzi (Protozoa: Kinetoplastida). Parasitology 2007; 134:1649-1656.

8. Da Silva CB, Guterres SS, Weisbeimer V, Schapoval EES: Antifungal activity of the lemongrass oil and citral against Candida spp. Braz J Infect Dis 2008;12:63-66.

9. Irkin R, Korukluoglu M: Effectiveness of Cymbopogon citratus L. essential oil to inhibit the growth of some filamentous fungi and yeasts. J Med Food 2009;12:193-197.

10. Oliveira VC, Moura DM, Lopes JA, de Andrade PP, da Silva NH, Figueiredo RC: Effects of essential oils from Cymbopogon citratus (DC) Stapf., Lippia sidoides Cham., and Ocimum gratissimum L. on growth and ultrastructure of Leishmania chagasi promastigotes. Parasitol Res 2009;104:1053-1059.

11. Minami M, Kita M, Nakaya T, Yamamoto T, Kuriyama H, Imanishi $\mathrm{J}$ : The inhibitory effect of essential oils on herpes simplex virus type1 replication in vitro. Microbiol Immunol 2003;47:681-684.

12. Sforcin JM, Amaral JT, Fernandes A Jr, Sousa JP, Bastos JK: Lemongrass effects on IL-1 $\beta$ and IL-6 production by macrophages. Nat Prod Res 2009;23:1151-1159.

13. Choi H-S, Song HS, Ukeda H, Sawamura M: Radical-scavenging activities of citrus essential oils and their components: detection using 1,1-diphenyl-2-picrylhydrazyl. J Agric Food Chem 2000;48:4156-4161.

14. Melo SF, Soares SF, da Costa RF, et al:: Effect of the Cymbopogon citratus, Maytenus ilicifolia and Baccharis genistelloides extracts against the stannous chloride oxidative damage in Escherichia coli. Mutat Res 2001;496:33-38.

15. Cheel J, Theoduloz C, Rodrguez J, Schmeda-Hirschmann G: Free radical scavengers and antioxidants from lemongrass (Cymbopogon citratus (DC.) Stapf.). J Agric Food Chem 2005;53:2511-2517.

16. Rabbani SI, Devi K, Khanam S, Zahra N: Citral, a component of lemongrass oil inhibits the clastogenic effect of nickel chloride in mouse micronucleus test system. Pak J Pharm Sci 2006;19:108-113.

17. Tapia A, Cheel J, Theoduloz C, et al.: Free radical scavengers from Cymbopogon citratus (DC.) STAPF plants cultivated in bioreactors by the temporary immersion (TIS) principle. $\underline{Z \text { Nat- }}$ urforsch C 2007;62:447-457.

18. Pereira RP, Fachinetto R, Prestes AS, et al.: Antioxidant effects of different extracts from Melissa officinalis, Matricaria recutita and Cymbopogon citratus. Neurochem Res 2009;34:973-983.

19. Mitić-Ćulafić C, Žegura B, Nikolić B, Vuković-Gačić B, Knežević-Vukčević J, Filipič M: Protective effect of linalool, myrcene and eucalyptol against t-butyl hydroperoxide induced genotoxicity in bacteria and cultured human cells. Food Chem Toxicol 2009;47:260-266.

20. Carnesecchi S, Schneider Y, Ceraline J, et al.: Geraniol, a component of plant essential oils, inhibits growth and polyamine biosynthesis in human colon cancer cells. J Pharmacol Exp Ther 2001;298:197-200.

21. Duncan RE, Lau D, El-Sohemy A, Archer MC: Geraniol and $\beta$ ionone inhibit proliferation, cell cycle progression, and cyclindependent kinase 2 activity in MCF-7 breast cancer cells independent of effects on HMG-CoA reductase activity. Biochem Pharmacol 2004;68:1739-1747. Erratum in Biochem Pharmacol 2005;69:361. 
22. Suaeyun R, Kinouchi T, Arimochi H, Vinitketkumnuem U, Ohnishi Y: Inhibitory effects of lemon grass (Cymbopogon citratus, Stapf) on formation of azoxymethane-induced DNA adducts and aberrant crypt foci in the rat colon. Carcinogenesis 2007;18:949-955.

23. Puatanachokchai R, Kishida H, Denda A, et al.: Inhibitory effects of lemon grass (Cymbopogon citratus, Stapf) extract on the early phase of hepatocarcinogenesis after initiation with diethylnitrosamine in male Fischer 344 rats. Cancer Lett 2002;183:9-15.

24. McLafferty FW, Stauffer D: The Wiley/NBS Registry of Mass Spectral Data. John Wiley \& Sons, New York, 1989.

25. Adams RP: Identification of Essential Oil Components by Gas Chromatography/Mass Spectroscopy, 3rd ed. Allured Publishing Corp., Carol Stream, IL, 2001.

26. Bidinotto LT, Spinardi-Barbisan AL, Rocha NS, Salvadori DM, Barbisan LF: Effects of ginger (Zingiber officinale Roscoe) on DNA damage and development of urothelial tumors in a mouse bladder carcinogenesis model. Environ Mol Mutagen 2006;47:624-630.

27. Bird RP, Good CK: The significance of aberrant crypt foci in understanding the pathogenesis of colon cancer. Toxicol Lett 2000;112-113:395-402.

28. Dias MC, Spinardi-Barbisan AL, Rodrigues MA, de Camargo JL, Terán E, Barbisan LF: Lack of chemopreventive effects of ginger on colon carcinogenesis induced by 1,2-dimethylhydrazine in rats. Food Chem Toxicol 2006;44:877-884.

29. De Moura NA, Grassi TF, Rodrigues MA, Barbisan LF: Potential effects of the herbicide Diuron on mammary and urinary bladder two-stage carcinogenesis in a female Swiss mouse model. Arch Toxicol 2010;84:165-173.

30. Zapaterini JR, Bidinotto LT, Rodrigues MA, Barbisan LF: Chemopreventive effects of mate against mouse mammary and colon carcinogenesis. Hum Exp Toxicol 2010;29:175-185.

31. Levin S, Bucci TJ, Cohen SM, et al.: The nomenclature of cell death: recommendations of an ad hoc Committee of the Society of Toxicologic Pathologists. Toxicol Pathol 1999;27:484-490.

32. Poliseno L, Mariani L, Collecchi P, Piras A, Zaccaro L, Rainaldi G: Bcl2-negative MCF7 cells overexpress p53: implications for the cell cycle and sensitivity to cytotoxic drugs. Cancer Chemother Pharmacol 2002;50:127-130.

33. Schaneberg BT, Khan IA: Comparison of extraction methods for marker compounds in the essential oil of lemon grass by GC. $\underline{J}$ Agric Food Chem 2002;50:1345-1349.

34. Barbosa LC, Pereira UA, Martinazzo AP, Maltha CR, Teixeira RR, Melo Ede C: Evaluation of the chemical composition of Brazilian commercial Cymbopogon citratus (D.C.) Stapf samples. Molecules 2008;13:1864-1874.

35. Van Zeeland AA, de Groot AJ, Mohn GR, et al.: Reduced methylation-induced mutagenesis in rat splenocytes in vivo by sub-chronic low dose exposure to N-metyl-N-nitrosourea. $\underline{\text { Mutat }}$ Res 2008;640:131-138.

36. Kyrtopoulos SA, Anderson LM, Chhabra SK, et al.: DNA adducts and the mechanism of carcinogenesis and cytotoxicity of methylating agents of environmental and clinical significance. Cancer Detect Prev 1997;21:391-405.

37. Povey AC, Badawi AF, Cooper DP, et al.: DNA alkylation and repair in the large bowel: animal and human studies. $J$ Nutr 2002;132(11 Suppl):3518S-3521S.
38. Thompson HJ, Singh M: Rat models of premalignant breast disease. J Mammary Gland Biol Neoplasia 2000;5:409-420.

39. Gabriel U, Bolenz C, Michel MS: Experimental models for therapeutic studies of transitional cell carcinoma. Anticancer Res 2007;27:3163-171.

40. Rosenberg DW, Giardina C, Tanaka T: Mouse models for the study of colon carcinogenesis. Carcinogenesis 2008;30:183-196.

41. Potten CS, Li YQ, O'Connor PJO, Winton DJ: A possible explanation for the differential cancer incidence in the intestine, based on distribution of the cytotoxic effects of carcinogens in the murine large bowel. Carcinogenesis 1992;13:2305-2312.

42. Norman JT, Howlett AR, Spacey GD, Hodges GM: Effects of treatment with $\mathrm{N}$-methyl-N-nitrosurea, artificial sweeteners, and cyclophosphamide on adult rat urinary bladder in vitro. $\underline{\mathrm{Lab}} \mathrm{In}$ vest 1987;57:429-438.

43. Delp CR, Treves JS, Banerjee MR: Neoplastic transformation and DNA damage of mammary mouse epithelial cells by N-methyl-Nnitrosurea in organ culture. Cancer Lett 1990;55:31-37.

44. Hanahan D, Weinberg RA: Hallmarks of cancer: the next generation. Cell 2011;144:646-674.

45. Shilkaitis A, Green A, Steele V, Lubet R, Kelloff G, Christov K: Neoplastic transformation of mammary epithelial cells in rats is associated with decreased apoptotic cell death. Carcinogenesis 2000;21:227-233.

46. Strange R, Metcalfe T, Thackray L, Dang M: Apoptosis in normal and neoplastic mammary gland development. Microsc Res

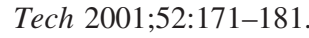

47. Singer B, Esslgmann JM: Site-specific mutagenesis: retrospective and prospective. Carcinogenesis 1991;12:949-955.

48. Pal R, Srivastava N, Chopra R, et al: Investigation of DNA damage response and apoptotic gene methylation pattern in sporadic breast tumors using high throughput quantitative DNA methylation analysis technology. Mol Cancer 2010;9:303.

49. Kuwana T, Newmeyer DD: Bcl-2-family proteins and the role of mitochondria in apoptosis. Curr Opin Cell Biol 2003;15:691-699.

50. Brunelle JK, Letai A: Control of mitochondrial apoptosis by the Bcl-2 family. J Cell Sci 2009;122:437-441.

51. Shilkaitis A, Green A, Steele V, Lubet R, Kelloff G, Christov K: Neoplastic transformation of mammary epithelial cells in rats is associated with decreased apoptotic cell death. $\underline{\text { Carcinogenesis }}$ 2000;21:227-233.

52. Strange R, Metcalfe T, Thackray L, Dang M: Apoptosis in normal and neoplastic mammary gland development. Microsc Res Tech 2001;52:171-181.

53. Williams GM: Chemically-induced preneoplastic lesions in rodents as indicators of carcinogenic activity. In: IARC Scientific Publications No. 146: The Use of Short- and Medium-Term Tests for Carcinogens and Data on Genetic Effects in Carcinogenic Hazard Evaluation (McGregor DB, Rice JM, Venitt S, eds.). IARC, Lyon, 1999, pp. 185-202.

54. Lipkin M, Yang K, Edelmann W, Xue L, Fan K, Risio M, Newmark H, Kucherlapati R: Preclinical mouse models for cancer chemoprevention studies. Ann N Y Acad Sci 1999;889:14-19.

55. Bidinoto LT, Costa CARA, Salvadori DMF, Costa M, Rodrigues MAM, Barbisan LF: Protective effects of lemongrass (Cymbopogon citratus STAPF essential oil on DNA damage and

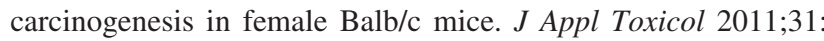
$536-544$. 
This article has been cited by:

1. Mariana F. Fragoso, Monize G. Prado, Luciano Barbosa, Noeme S. Rocha, Luis F. Barbisan. 2012. Inhibition of Mouse Urinary Bladder Carcinogenesis by Açai Fruit (Euterpe oleraceae Martius) Intake. Plant Foods for Human Nutrition 67:3, 235-241. [CrossRef] 